\title{
FAKTOR-FAKTOR YANG BERHUBUNGAN DENGAN PEMBERIAN ASI PADA IBU PASCA SALIN DI RSUD. DR PIRNGADI MEDAN
}

\section{Vitrilina Hutabarat ${ }^{1}$, Stefani Anastasia Sitepu ${ }^{2}$ Novita Br Ginting Munthe $^{3}$}

\author{
INSTITUT KESEHATAN DELI HUSADA DELI TUA \\ Jl. Besar No. 77 Deli Tua Kab. Deli Serdang Sumatera Utara \\ e-mail : vitrilinahutabarat@gmail.com
}

DOI: https://doi.org/10.35451/jkk.v1i2.124

\begin{abstract}
Breast milk is the liquid produced by the secretion of the mother's breast gland, which is given to babies from birth for 6 months, without adding or replacing with other foods or drinks. The Indonesian government targets exclusive breastfeeding coverage of $80 \%$. The results of the 2010 Riskesdas in North Sumatra only reached 20.2\%. From year to year, it declined, especially in Medan.This study aims to determine the factors associated with breastfeeding in postpartum mothers at the RSUD. Dr. Pirngadi Medan in 2015. The study design used was cross sectional in the primary data consisting of 48 respondents. The study was conducted on March 28-April 28, 2015 using a questionnaire filled out by the respondents themselves. Analysis of the data used is chi square. The results showed that most of the middle age were $56.3 \%$, secondary education was $64.6 \%$, working IRT as much as $100 \%$, delivery by sectio caesarea as much as $70.8 \%$, knowledgeable as much as $79.2 \%$, sources of information from officers health as much as $62.5 \%$, and those who received support as much as $83.3 \%$. Proportion of breastfeeding to postpartum mothers at Dr. Pirngadi Medan is $83.3 \%$, has more fulfilled the national target $(80 \%)$. Factors related to breastfeeding in this study were knowledge (predisposing factors), sources of information (enabling factors) and husband / family support (reinforcing factors). From the results of this study it can be concluded that good knowledge (predisposing factors), sources of information from health workers (enabling factors) and husband / family support (reinforcing factors) can influence breastfeeding in postpartum mothers.
\end{abstract}

Keywords: Predisposing, enabling, reinforcing, breast milk factors

\section{Pendahuluan}

Indikator utama derajat kesehatan masyarakat adalah angka kematian bayi (AKB) atau Infant Mortality Rate (IMR). Faktor-faktor yang terikat dengan AKB ini adalah status gizi ibu pada waktu melahirkan dan gizi bayi itu sendiri, yang juga merupakan faktor tidak langsung maupun langsung sebagai penyebab kematian bayi (Notoatmodjo, 2007).

Melihat angka kematian bayi di Indonesia yang masih relatif tinggi 
dibanding dengan Negara ASEAN lainnya yaitu 4,6 kali lebih tinggi dari Malaysia, 1,3 kali lebih tinggi dari Filipina, dan 1,8 kali lebih tinggi dari Thailand (GOIUNICEF, 2003). Dari data diatas, sekitar $80 \%$ kematian neonatal ini terjadi pada minggu pertama, menunjukkan masih rendahnya status kesehatan ibu dan bayi baru lahir, menyusui sangat signifikan dalam menurunkan kematian anak. Hal ini berarti memiliki peranan penting dalam pencapaian MDG's (Menkes RI, 2010).

Menyusui menurut Roesli (2000) adalah suatu proses alamiah, bahkan berjuta-juta ibu diseluruh dunia berhasil menyusui bayinya tanpa pernah membaca buku tentang ASI. Walaupun demikian, dalam lingkungan kebudayaan kita saat ini untuk melakukan hal yang alamiah tidaklah selalu mudah. Dengan meningkatnya ilmu pengetahuan seiring dengan kemajuan teknologi haruslah meningkat pengetahuan lama khususnya menyusui, justru malah terlupakan. Padahal kehilangan pengetahuan tentang menyusui berarti kehilangan besar, karena menyusui adalah suatu pengetahuan yang selama berjuta-juta tahun mempunyai peran penting dalam mempertahankan kehidupan manusia.

Berdasarkan Peraturan Pemerintah Republik Indonesia (PPRI) 2012, ASI adalah cairan hasil sekresi kelenjar payudara ibu, dan Asi Eksklusif adalah Asi yang diberikan kepada bayi sejak dilahirkan selama 6 (enam) bulan, tanpa menambahkan dan atau mengganti dengan makanan atau minuman lain.

Penelitian di enam negara berkembang oleh WHO (2000), resiko kematian bayi antara usia 9-12 bulan meningkat $40 \%$ jika bayi tersebut tidak disusui. Untuk bayi berusia dibawah 2 bulan, angka kematian bayi meningkat menjadi $48 \%$ sekitar $40 \%$ kematian balita terjadi satu bulan pertama kehidupan bayi. Kematian pada neonatal dini terjadi pada hari pertama (Komalarasi, 2003). Penyebab yang mendasari pada 54\% kematian bayi adalah gizi kurang. Data organisasi kesehatan dunia (WHO) menunjukkan ada 170 juta anak di dunia mengalami gizi kurang. Sebanyak 3 juta anak diantaranya meninggal tiap tahun akibat kurang gizi karena tidak disusui.

Berdasarkan Survei Demografi \& Kesehatan Indonesia SDKI (2007) angka kematian bayi (AKB) di Indonesia yaitu 35 bayi per 1000 kelahiran hidup pada tahun 2004. Apabila dirincikan 157.000 bayi meninggal per tahun atau 430 bayi per hari. Angka Kematian Bayi (AKB) menjadi turun 34 per 1000 kelahiran hidup pada tahun 2007. Walaupun turun namun $A K B$ di Indonesia masih sangat tinggi dibanding negara lain, diperkirakan setiap jam, delapan belas (18) bayi di Indonesia meninggal dunia. Sementara target yang akan dicapai sesuai kesepakatan MDG's tahun 2015, AKB menjadi 24 per 1000 kelahiran hidup. 
Angka kematian bayi di Indonesia berbeda-beda di setiap provinsi, di provinsi sumatera utara kematian bayi sangat tinggi yaitu mencapai > 49 per 1000 kelahiran hidup (Profil Kesehatan Indonesia, 2008). Hasil Riskesdas 2010 di Sumatera Utara baru mencapai 20,2 \% proses pemberian ASI kurang dari satu jam, dan pencapaian program ASI eksklusif di kota Medan pada tahun 2009 sebesar 1,32 \%, masih sangat rendah dibandingkan pencapaian propinsi Sumatera Utara maupun pencapaian Nasional (Profil Dinkes Medan).

Perilaku ASI Eksklusif di Indonesia secara keseluruhan cenderung menurun. Berdasarkan Hasil Survei Demografi Kesehatan Indonesia Tahun 2007, pemberian ASI Eksklusif di bawah 6 (enam) bulan menurun, dibandingkan dengan survei yang sama dilakukan pada tahun 2002.

Ibu memerlukan dukungan dari orang-orang sekitarnya untuk menunjang keberhasilan perilaku ASI Eksklusif, baik itu dari petugas kesehatan atau dari keluarga. Faktor-faktor penguat berupa peranan tenaga kesehatan, dukun bayi, dan keluarga sebagian besar bersifat negatif sehingga terjadi kegagalan pemberian ASI Eksklusif (Diana, 2007).

Sekalipun ASI begitu sempurna bagi bayi, tidak akan berarti banyak bila perilaku ibu sendiri tidak mendukung tercapainya ASI Eksklusif. Sementara pada kenyataan di masyarakat saat ini, cakupan ASI semakin menurun di daerah-daerah di Indonesia termasuk di kota Medan.

Dengan latar belakang pemikiran diatas, penulis tertarik untuk mengadakan penelitian dengan judul faktor-faktor yang berhubungan dengan pemberian ASI pada ibu pasca salin di RSUD Dr Pirngadi Medan Tahun 2015.

Tujuan penelitian ini adalah untuk mengetahui faktor-faktor apa saja yang berhubungan dengan pemberian ASI pada ibu pasca salin di RSUD. Dr Pirngadi di daerah Kota Medan Tahun 2015.

\section{Metode Penelitian}

Penelitian ini menggunakan jenis penelitian analitik dengan metode pendekatan Cross sectional yang bertujuan untuk mengetahui faktor-faktor yang berhubungan dengan pemberian ASI pada ibu pasca salin di RSUD. Dr Pirngadi Medan. Tehnik pengumpulan data dalam penelitian ini adalah total sampling yaitu mengambil semua sampel dari populasi yaitu ibu pasca salin yang melahirkan bayi hidup 0-5 hari, dapat membaca, dapat memahami pertanyaan yang diberikan dan bersedia menjadi responden di RSUD Dr. Pirngadi Medan sebanyak 48 orang. Alat yang digunakan untuk mengumpulkan data adalah kuesioner. Kuesioner sudah di uji validitas dan reliabilitas dengan nilai Cronbach's alpha yang didapat 0,952. Analisis data menggunakan analisis univariat untuk mendapatkan gambaran 
distribusi frekuensi dan persentase dari tiap variabel dan analisis bivariat untuk mengetahui hubungan satu variabel bebas dengan satu variabel terikat, dilakukan uji Chi-Square dengan nilai $\mathrm{p}<$ 0,05 . Pedoman dalam menerima hipotesa: jika hasil uji menunjukkan nilai $\mathrm{p} \leq 0,05$ maka Ho ditolak atau ada hubungan antar variabel bermakna (signifikan), dan apabila $\mathrm{p} \geq 0,05$ maka Ho gagal ditolak yaitu tidak ada hubungan antar variabel bermakna (signifikan). Sedangkan untuk mengetahui besarnya faktor resiko maka digunakan analisis odds ratio (OR) dengan interpretasi sebagai berikut:

Bila nilai $\mathrm{OR}=1$ berarti variabel diduga merupakan faktor resiko tidak mempunyai pengaruh terhadap terjadinya efek, atau dengan kata lain bersifat netral.

Bila nilai $O R>1$ berarti variabel diduga merupakan faktor resiko mempunyai pengaruh terhadap efek, atau dengan kata lain merupakan faktor resiko terjadinya efek.

Bila $O R<1$ berarti variabel yang diteliti diduga dapat mengurangi terjadinya efek atau faktor pencegah.

\section{Hasil dan Pembahasan}

Hasil dan pembahasan dalam penelitian ini adalah:
Tabel 1. Distribusi Frekuensi Karakteristik Responden di RSUD Dr. Pirngadi Medan Tahun $2015(n=48)$

\begin{tabular}{|c|c|c|}
\hline Variabel & $\mathbf{n}$ & $\%$ \\
\hline $\begin{array}{l}\text { Variabel Independen } \\
\text { Umur } \\
1=\text { Muda }(15-29) \\
2=\text { Sedang }(30-39)\end{array}$ & $\begin{array}{l}21 \\
27\end{array}$ & $\begin{array}{l}43,8 \\
56,3\end{array}$ \\
\hline $\begin{array}{l}\text { Pendidikan } \\
1=\text { Dasar (SD,SLTP) } \\
2=\text { Menengah (SLTA,PT) }\end{array}$ & $\begin{array}{l}17 \\
31\end{array}$ & $\begin{array}{l}35,4 \\
64,6\end{array}$ \\
\hline $\begin{array}{l}\text { Pekerjaan } \\
1=\text { IRT } \\
2=\text { Wiraswasta } \\
3=\text { PNS }\end{array}$ & $\begin{array}{l}48 \\
0 \\
0\end{array}$ & $\begin{array}{l}100,0 \\
0 \\
0\end{array}$ \\
\hline $\begin{array}{l}\text { Jenis Persalinan } \\
1=\text { Normal } \\
2=\mathrm{SC}\end{array}$ & $\begin{array}{l}14 \\
34\end{array}$ & $\begin{array}{l}29,2 \\
70,8\end{array}$ \\
\hline $\begin{array}{l}\text { Pengetahuan } \\
1=\text { Baik } \\
2=\text { Kurang }\end{array}$ & $\begin{array}{l}38 \\
10\end{array}$ & $\begin{array}{l}79,2 \\
20,8\end{array}$ \\
\hline $\begin{array}{l}\text { Sumber Informasi } \\
1=\text { Media } \\
2=\text { Petugas Kesehatan }\end{array}$ & $\begin{array}{l}18 \\
30\end{array}$ & $\begin{array}{l}37,5 \\
62,5\end{array}$ \\
\hline $\begin{array}{l}\text { Dukungan suami/keluarga } \\
1=\text { Ya } \\
2=\text { Tidak }\end{array}$ & $\begin{array}{l}40 \\
8\end{array}$ & $\begin{array}{l}83,3 \\
16,7\end{array}$ \\
\hline
\end{tabular}

Berdasarkan table 1 diperoleh sebagian besar berumur sedang sebanyak 56,3\%, berpendidikan menengah sebanyak 64,6\%, berpengetahuan baik 79,2\%, memiliki pekerjaan sebagai ibu rumah tangga sebanyak $100 \%$, bersalin secara sectio caesarea sebanyak 70,8\%, sumber informasi yang didapat dari petugas kesehatan sebanyak $62,5 \%$, dan yang mendapat dukungan sebanyak $83,3 \%$. 
Tabel 2. Distribusi Responden Menurut Pemberian ASI pada Ibu Pasca Salin di RSUD Dr. Pirngadi Medan Tahun 2015 $(n=48)$

\section{Pemberian Frekuensi Persentase ASI}

\begin{tabular}{ccc}
\hline Ya & 40 & 83,3 \\
\hline Tidak & 8 & 16,7
\end{tabular}

Berdasarkan tabel 2 menunjukkan bahwa mayoritas ibu pasca salin yang memberikan ASI di RSUD Dr. Pirngadi Medan tahun 2015 sebanyak 83,3\% sementara yang tidak memberikan ASI sebanyak $16,7 \%$.

Tabel 3. Distribusi Hubungan Karakteristik Responden dengan Pemberian ASI di RSUD Dr. Pirngadi Medan Tahun $2015(n=48)$

\begin{tabular}{|c|c|c|c|c|c|c|}
\hline \multicolumn{7}{|c|}{ Pemberian ASI } \\
\hline \multirow[t]{2}{*}{ Variabel } & \multicolumn{2}{|c|}{$\mathbf{Y a}$} & \multicolumn{2}{|c|}{ Tidak } & \multicolumn{2}{|c|}{ Total } \\
\hline & $f$ & $\%$ & f & $\%$ & f & $\%$ \\
\hline \multicolumn{7}{|c|}{$\begin{array}{l}\text { Faktor } \\
\text { Predisposisi } \\
\text { Umur }\end{array}$} \\
\hline Muda & 16 & 76,2 & 5 & 23,8 & 21 & 100 \\
\hline Sedang & 24 & 88,9 & 3 & 11,1 & 27 & 100 \\
\hline \multicolumn{7}{|l|}{ Pendidikan } \\
\hline Dasar & 13 & 76,5 & 4 & 23,5 & 17 & 100 \\
\hline Menengah & 27 & 87,1 & 4 & 12,9 & 31 & 100 \\
\hline \multicolumn{7}{|l|}{ Pekerjaan } \\
\hline IRT & 40 & 83,3 & 8 & 16,7 & 48 & 100 \\
\hline Wiraswasta & 0 & 0 & 0 & 0 & 0 & 0 \\
\hline PNS & 0 & 0 & 0 & 0 & 0 & 0 \\
\hline \multicolumn{7}{|l|}{$\begin{array}{l}\text { Jenis } \\
\text { Persalinan }\end{array}$} \\
\hline Normal & 12 & 85,7 & 2 & 14,3 & 14 & 100 \\
\hline SC & 28 & 82,4 & 6 & 17,6 & 34 & 100 \\
\hline \multicolumn{7}{|c|}{$\begin{array}{l}\text { Pengetahua } \\
\text { n }\end{array}$} \\
\hline Baik & 35 & 92,1 & 3 & 7,9 & 38 & 100 \\
\hline Kurang & 5 & 50,0 & 5 & 50,0 & 10 & 100 \\
\hline $\begin{array}{l}\text { Faktor } \\
\text { Pemungkin } \\
\text { Sumber } \\
\text { Informasi }\end{array}$ & & & & & & \\
\hline
\end{tabular}

\begin{tabular}{|c|c|c|c|c|c|c|}
\hline Media & 12 & 66,7 & 6 & 33,3 & 18 & 100 \\
\hline Petugas Kes & 28 & 93,3 & 2 & 6,7 & 30 & 100 \\
\hline \multicolumn{7}{|l|}{$\begin{array}{l}\text { Faktor } \\
\text { Pendukung } \\
\text { Dukungan } \\
\text { Keluarga }\end{array}$} \\
\hline & $\begin{array}{c}40 \\
0\end{array}$ & $\begin{array}{c}100 \\
0\end{array}$ & $\begin{array}{l}0 \\
8\end{array}$ & $\begin{array}{c}0 \\
100\end{array}$ & $\begin{array}{c}40 \\
8\end{array}$ & $\begin{array}{l}100 \\
100\end{array}$ \\
\hline
\end{tabular}

Berdasarkan tabel 3 diatas diperoleh sebagian besar yang memberikan ASI berumur sedang sebanyak 88,9\%, berpendidikan menengah sebanyak 87,1\%, memiliki pekerjaan sebagai ibu rumah tangga (IRT) sebanyak 83,3\%, bersalin secara sectio caesarea (SC) sebanyak 82,4\%, berpengetahuan baik sebanyak 92,1\%, sumber informasi yang didapat dari petugas kesehatan sebanyak 93,3\% dan yang mendapat dukungan suami/keluarga sebanyak 100\%. 
Tabel 4. Distribusi Frekuensi Hubungan Faktor Predisposisi, Faktor Pemungkin, Faktor Penguat dengan Pemberian ASI di RSUD Dr Pirngadi Medan Tahun 2015 $(n=48)$

\begin{tabular}{|c|c|c|c|c|c|c|c|c|}
\hline \multicolumn{9}{|c|}{ Pemberian ASI } \\
\hline & \multicolumn{2}{|c|}{ YA } & \multicolumn{2}{|c|}{ TIDAK } & \multicolumn{2}{|c|}{ Total } & \multirow{2}{*}{$\begin{array}{l}\mathbf{O} \\
\mathbf{R} \\
\end{array}$} & \multirow[t]{2}{*}{$\mathbf{p}$} \\
\hline & $\mathbf{n}$ & $\%$ & $\mathrm{n}$ & $\%$ & $\mathrm{~N}$ & $\%$ & & \\
\hline \multicolumn{9}{|l|}{$\begin{array}{l}\text { Faktor } \\
\text { predisp } \\
\text { osisi }\end{array}$} \\
\hline Umur & 16 & 76 & 5 & 23 & 21 & 10 & 0 & 0 , \\
\hline \multirow[t]{2}{*}{ Muda } & 24 & ,2 & 3 &, 8 & 27 & 0 & 40 & 27 \\
\hline & & 88 & & 11 & & 10 & 0 & 2 \\
\hline Sedang & &, 9 & &, 1 & & 0 & & \\
\hline \multicolumn{9}{|l|}{ Pendidi } \\
\hline kan & 13 & 76 & 4 & 23 & 17 & 10 & 0 & 0 \\
\hline \multirow{2}{*}{ Dasar } & 27 &, 5 & 4 &, 5 & 31 & 0 & 48 & 42 \\
\hline & & 87 & & 12 & & 10 & 1 & \\
\hline $\begin{array}{l}\text { Menen } \\
\text { gah }\end{array}$ & & ,1 & & ,9 & & 0 & & \\
\hline \multicolumn{9}{|l|}{$\begin{array}{l}\text { JenisPe } \\
\text { rsalina }\end{array}$} \\
\hline \multirow[t]{2}{*}{$\mathrm{n}$} & 12 & 85 & 2 & 14 & 14 & 10 & 1, & 1, \\
\hline & 28 & ,7 & 6 & ,3 & 34 & 0 & 28 & 00 \\
\hline Normal & & 82 & & 17 & & 10 & 6 & 0 \\
\hline $\mathrm{SC}$ & & ,4 & & ,6 & & 0 & & \\
\hline \multicolumn{9}{|l|}{$\begin{array}{l}\text { Penget } \\
\text { ahuan }\end{array}$} \\
\hline \multirow[t]{2}{*}{ Baik } & 35 & 92 & 3 & 7 & 38 & 10 & 11 & 0 , \\
\hline & 5 &, 1 & 5 & 9 & 10 & 0 & ,6 & 00 \\
\hline \multirow[t]{2}{*}{ Kurang } & & 50 & & 50 & & 10 & 67 & 6 \\
\hline & &, 0 & &, 0 & & 0 & & \\
\hline \multicolumn{9}{|l|}{ Faktor } \\
\hline \multicolumn{9}{|l|}{ gkin } \\
\hline \multicolumn{9}{|l|}{ Sumber } \\
\hline Inform & 12 & 66 & 6 & 33 & 18 & 10 & 0 & 0 , \\
\hline asi & 28 &, 7 & 2 &, 3 & 30 & 0 & 14 & 04 \\
\hline \multirow[t]{2}{*}{ Media } & & 93 & & 6 & & 10 & 3 & 0 \\
\hline & & ,3 & & 7 & & 0 & & \\
\hline \multicolumn{9}{|l|}{ Pet.Kes } \\
\hline \multicolumn{9}{|l|}{ Faktor } \\
\hline \multicolumn{9}{|l|}{ Pengua } \\
\hline Dukun & 40 & 10 & 0 & 0 & 40 & 10 & - & 0 , \\
\hline gan & 0 & 0 & 8 & 10 & 8 & 0 & & 00 \\
\hline Ya & & 0 & & 0 & & 10 & & 0 \\
\hline Tidak & & & & & & 0 & & \\
\hline
\end{tabular}

Berdasarkan tabel 4 diatas menunjukkan bahwa variabel yang mempunyai nilai $\mathrm{p}<0,05$ adalah pengetahuan $p=0,006$, sumber informasi $p=0,040$ dan dukungan suami/keluarga $p=0,000$. Hal ini berarti variabel tersebut memiliki hubungan bermakna dengan pemberian ASI.

\section{Pembahasan}

1. Pemberian ASI pada ibu pasca salin Hasil analisis univariat diketahui proporsi ibu yang memberikan ASI adalah sebanyak $83,3 \%$. Sementara ibu tidak memberikan ASI adalah sebanyak $16,7 \%$ dikarenakan puting lecet, memiliki riwayat penyakit hepatitis $B$, dan sebagian lagi karena tidak memiliki dukungan suami/keluarga dalam memberikan ASI.

Berdasarkan Survei Demografi Kesehatan Indonesia (SDKI) tahun 2003 menemukan hanya $40 \%$ bayi mendapatkan ASI eksklusif dan turun menjadi 32,8\% tahun 2007. Data Riskesdas 2010 menemukan bahwa persentase proses mulai menyusui kurang dari 1 jam di Sumatera Utara hanya $20,2 \%$. Proporsi hasil penelitian ini jauh lebih tinggi dibanding proporsi SDKI, dan proporsi ini sudah sebanding dengan yang diharapkan sesuai komitment pemerintah Indonesia yaitu $80 \%$.

Tingginya proporsi pemberian ASI dikarenakan kebijakan yang meningkatkan Kesehatan Ibu dan Anak di RSUD Dr Pirngadi yaitu punya standar operasional dalam menolong persalinan 
termasuk pemberian ASI setelah bersalin, dan proporsi ibu post partum yang memberikan ASI pada penelitian ini relevan bila melihat hasil perhitungan statistik variabel independennya yaitu memiliki reponden yang berpendidikan menengah, berpengetahuan baik dan mendapat informasi tentang pemberian ASI dari petugas kesehatan.

\section{Hubungan Faktor Predisposisi} dengan Pemberian ASI pada ibu post partum

a. Umur

Hasil analisis bivariat diperoleh sebagian besar responden berumur sedang memberikan ASI yaitu 88,9\%, dengan $p=0,272$, yang berarti pada alpha $5 \%$ tidak ada hubungan yang signifikan antara umur dengan pemberian ASI. Hasil analisis juga diperoleh OR adalah 0,400 artinya ibu yang berumur 30-39 tahun memiliki peluang 0,400 kali memberikan ASI dibandingkan ibu yang berumur 15-29 tahun.

Hasil analisis ini sesuai dengan penelitian yang dilakukan oleh Solihah $\mathrm{Li}$, dkk (2007) di kabupaten Garut Jawa Barat, diketahui dari 640 ibu yang memiliki bayi $0-11$ bulan di kab. Garut ditemukan bahwa umur ibu tidak ada hubungan yang bermakna antara umur dengan pemberian ASI $(p=0,3222)$.

Hasil analisis bivariat pada penelitian ini tidak ditemukan adanya perbedaan hubungan yang bermakna karena kemungkinan ketidaktepatan dalam pengkategorian umur. Disamping itu diperkirakan karena faktor umur bukanlah satu-satunya variabel yang berhubungan dengan pemberian ASI. Sehingga meskipun usia ibu sudah siap untuk menyusui, tetapi bila tidak didukung dengan faktor lain seperti pengetahuan yang baik, dukungan dari suami/keluarga atau niat menyusui, maka pemberian ASI tetap tidak akan dilakukan.

b. Pengetahuan

Pengetahuan berbanding lurus dengan pendidikan, karena semakin tinggi pendidikan maka akan semakin baik juga pengetahuan seseorang. Dengan pengetahuan yang baik akan menjadi salah satu bekal bagi ibu dalam proses pemberian ASI. Menurut Notoadmodjo (2003), pengetahuan merupakan hal yang sangat penting untuk terbentuknya suatu tindakan seseorang. Sejumlah penelitian telah dilakukan belakangan ini, termasuk juga pada penelitian ini ditemukan $92,1 \%$ ibu berpengetahuan baik berhasil memberikan ASI.

Berbeda dengan penelitian Roesli (2009) terhadap 900 ribu di sekitar Jabotabek tahun 1955 telah mengutip bahwa sekitar 98\% ibu-ibu tersebut menyusui dan $37,9 \%$ diantaranya tidak pernah mendengarkan informasi tentang ASI.

Dalam penelitian ini ditemukan hubungan yang bermakna antara pengetahuan dengan pemberian ASI 
$p=0,006$. Hasil analisis juga diketahui OR adalah 11,66 artinya ibu yang berpengetahuan baik memiliki peluang 11,66 kali untuk memberikan ASI dibanding dengan ibu yang berpengetahuan kurang. Hal ini juga sesuai dengan penelitian Solihah, dkk (2007) yang menunjukkan adanya hubungan yang bermakna antara pengetahuan dengan pemberian ASI, responden yang yang memiliki pengetahuan baik tentang pemberian ASI berpeluang 13,26 kali pada ibu yang berpengetahuan kurang.

\section{Berdasarkan}

responden terhadap pertanyaan, sebagian besar responden menjawab dengan benar tentang makanan bayi yang paling sempurnah adalah ASI sebanyak 97,9\%. Hal ini sesuai dengan tindakan ibu pasca salin yang mayoritas telah memberikan ASI kepada bayinya. Dan sebagian besar responden menjawab salah tentang masalah menyusui pada bayi sebanyak 58,3\%. Hal ini dikarenakan responden tidak memiliki masalah menyusui pada bayi saat memberikan ASI.

\section{c. Pendidikan}

Untuk pendidikan responden dengan kategori tinggi didapat pada responden yang berpendidikan menengah yaitu $87,1 \%$, sedangkan yang berpendidikan rendah dan memberikan ASI sebanyak $76,5 \%$ dengan $p=0,428$ artinya pada alpha 5\% dapat disimpulkan tidak ada perbedaan proporsi antara ibu yang berpendidikan menengah dengan ibu yang berpendidikan rendah dalam memberikan ASI. Hasil analisis juga diketahui OR adalah 0,481 artinya ibu yang berpendidikan menengah berpeluang 0,481 kali memberikan ASI dibanding dengan ibu yang berpendidikan dasar.

Hasil analisis yang tidak menunjukkan hubungan antara tingkat pendidikan bisa saja terjadi karena pendidikan bukan satu-satunya variabel yang berhubungan dengan pemberian ASI. Selain itu diperkirakan pendidikan yang telah dilalui memang tidak memfokuskan tentang pemberian ASI. Pendidikan merupakan bagian dari faktor yang diharapkan supaya ibu yang memiliki pendidikan tinggi akan lebih mudah serta akan lebih mampu untuk menyerap informasi. Oleh karena itu pendidikan tetap harus menjadi perhatian apalagi jika dilihat dari beberapa hasil penelitian diberbagai Negara Asia dan Afrika yang membuktikan bahwa ibu dengan pendidikan tinggi akan berpengaruh positif terhadap kesehatan ibu, bayi dan anaknya ( Suheryan, Yayan. 2005)

d. Jenis persalinan

Hasil analisis menunjukkan bahwa ibu yang melahirkan secara Sectio caesarea dan memberikan ASI sebanyak $82,4 \%$, sedangkan ibu yang melahirkan dengan normal dan memberikan ASI sebanyak $85,7 \%$ dengan $p=1,00$, berarti 
tidak ada hubungan yang bermakna antara jenis persalinan dengan pemberian ASI. Hasil analisis juga diperoleh OR adalah 1,286 artinya Ibu yang bersalin secara SC memiliki peluang 1,286 kali untuk memberikan ASI dibanding ibu yang bersalin normal.

Tidak adanya hubungan antara jenis persalinan dengan pemberian ASI, hal ini kemungkinan disebabkan oleh karena jumlah ibu yang bersalin secara SC lebih banyak dari pada ibu yang melahirkan normal di RSUD Dr. Pirngadi Medan.

3. Hubungan faktor pemungkin dengan pemberian ASI pada ibu pasca salin.

a. Sumber Informasi

Berdasarkan hasil uji bivariat diketahui bahwa ibu yang memperoleh informasi dari petugas kesehatan dan memberikan ASI adalah sebanyak 93,3\%, sedangkan ibu yang memperoleh informasi dari media dan memberikan ASI sebanyak $66,7 \%$ dengan nilai $p=0,018$ yang berarti ada hubungan yang bermakna antara sumber informasi dengan pemberian ASI. Hasil analisis juga diperoleh OR adalah 0,143 artinya ibu yang memperoleh informasi dari petugas kesehatan berpeluang 0,143 kali untuk memberikan ASI dibanding dengan ibu yang memperoleh informasi dari media.

Menurut pendapat Lukman dan Hendra (2008), bahwa informasi akan memberikan pengaruh pada pengetahuan seseorang. Meskipun seseorang memiliki pendidikan yang rendah tetapi jika ia mendapatkan informasi yang baik, maka akan dapat meningkatkan pengetahuan seseorang.

4. Hubungan faktor penguat dengan pemberian ASI pada ibu pasca salin

a. Dukungan suami/keluarga

Dalam penelitian ini didapat hasil bahwa ibu yang didukung oleh suami/keluarga dan memberikan ASI sebanyak $100 \%$ dengan $p=0,00$ yang berarti ada hubungan yang bermakna antara dukungan suami/keluarga dengan pemberian ASI.

Dukungan suami sangat berarti bagi istri. Pada ibu menyusui, suami merupakan orang terdekat yang diharapkan selalu berada disamping ibu. Suami mempunyai peran yang sangat penting dalam menentukan kelancaran reflex pengeluaran ASI atau left down reflex yang sangat dipengaruhi oleh keadaan emosi istri (Roesli, 2009).

Menurut Roesli (2009) bahwa ayah dapat berperan aktif dalam keberhasilan pemberian ASI dengan jalan memberikan dukungan secara emosional dan bantuanbantuan secara praktis. Dan dari semua dukungan bagi ibu menyusui, dukungan suami adalah dukungan yang paling berarti. Hal ini bersamaan dengan hasil peneliti. Dan didalam salah satu langkah keberhasilan ASI eksklusif menurut Roesli (2009), dengan menciptakan dukungan keluarga, baik teman dan sebagainya akan menuju keberhasilan menyusui. 


\section{Kesimpulan}

Berdasarkan karakteristik responden menunjukkan sebagian besar berumur sedang sebanyak $56,3 \%$, berpendidikan menengah sebanyak 64,6\%, berpengetahuan baik 79,2\%, memiliki pekerjaan sebagai ibu rumah tangga sebanyak $100 \%$, bersalin secara sectio caesarea sebanyak $70,8 \%$, sumber informasi dari petugas kesehatan sebanyak 62,5\%, dan yang mendapat dukungan sebanyak $83,3 \%$.

Proporsi pemberian ASI pada ibu pasca salin di RSUD Dr. Pirngadi Medan tahun 2015 sebesar 83,3\%. Cakupan ini jauh diatas cakupan nasional ASI eksklusif berdasarkan data Riskesdas 2010 menemukan bahwa persentase proses mulai menyusui kurang dari 1 jam di Sumatera Utara hanya 20,2\%.

Ada hubungan antara faktor predisposisi (pengetahuan) dengan pemberian ASI pada ibu pasca salin dimana $p=0,006$.

Ada hubungan antara faktor pemungkin (sumber informasi) dengan pemberian ASI pada ibu pasca salin dimana $p=0,040$.

Ada hubungan antara faktor penguat (dukungan suami/keluarga) dengan pemberian ASI pada ibu pasca salin dimana $p=0,00$.

\section{Daftar Pustaka}

Abdullah, G. (2012). Determinan Pemberian ASI Eksklusif pada ibu bekerja di Kementerian Kesehatan RI. Diambil tanggal 21 Juni 2015 dari www.doctos.com
Arini, H. (2012). Mengapa Seorang Ibu harus Menyusui. FlashBooks: Jogjakarta.

Ariani. (2009). Ibu Susui aKu. Khazanah Intelektual Anggota IKAPI: Bandung.

Arif Nurhaeni. (2009). ASI dan Tumbuh Kembang Bayi. Medpress : Yogyakarta.

Arikunto Suharsimi. (2006). Prosedur Penelitian Suatu Pendekatan Praktik (Revisi VI). PT Rineka Cipta: Jakarta.

Darwis, S.D. (2003). Metode Penelitian Kebidanan Prosedur,Kebijakan dan Etika. EGC: Jakarta.

Gustina, Ismail.,R \& Roselina,.E. (2008). Faktor-faktor yang berhubungan dengan perilaku pemberian kolostrum 24 jam pertama pada ibu post partum di RS Persahabatan Jakarta.

Hidayat Aziz. (2010). Metode Penelitian Kebidanan dan Teknik Analisis Data. Salemba Medika: Jakarta.

IDAI. (2008). Bedah ASI. Balai Pennerbit FKUI: Jakarta.

Josefa.,K.,G \& Margawati.,A.(2011). Faktor-faktor yang mempengaruhi perilaku pemberian ASI. Artikel. Fakultas Kedokteran Universitas Diponegoro.

Kementerian Kesehatan RI. (2010). Pedoman Pekan ASI Sedunia (PPAS). KKRI: Jakarta

King Savage, F. (1993). Menolong Ibu Menyusui. Gramedia Pustaka Utama: Jakarta.

Kodrat Laksono. (2010). Dahsyatnya ASI dan Laktasi. Media Baca: Yogyakarta.

Moody, J. dkk. (2006). Menyusui cara mudah praktis dan nyaman. Arcan: Jakarta. 
Machfoedz Ircham. (2010). Metodologi Penelitian Kuantitatif dan Kualitatif Bidang Kesehatan, Keperawatan, Kebidanan, Kedokteran. Fitramaya: Yokjakarta.

Mochtar, R. (1998). Sinopsis Obstetri. Ed2. Jakarta: EGC

Notoatmodjo Soekidjo. (2010). Metodologi Penelitian Kesehatan. Rineka Cipta: Jakarta.

Notoatmodjo Soekidjo. (2010). Promosi Kesehatan Teori dan Aplikasi. Rineka Cipta: Jakarta.

Notoatmodjo Soekidjo.(2005).Metodologi Penelitian Kesehatan. Rineka Cipta: Jakarta.

Prawirahardjo, S. (2002). Buku Panduan Praktis Pelayanan Kesehatan Maternal dan Neonatal. Bina Pustaka: Jakarta.

Proverawati, A., \& Rahmawati, E. (2010). Kapita Selekta ASI dan Menyusui. Nuka Medika: Yogyakarta.

Prasetyono, D.S. (2012). Buku Pintar ASI Eksklusif. Diva Press: Jogjakarta.

Riyadi., S.Y. (2012). Indonesia Cinta Sehat, Hari Kesehatan Nasional Ke48. Diambil tanggal 20 desember 2012 dari http://www.google.com/search?q=an gka+kematian+tahun+2012. Pdf

Riskesdas. (2010). Laporan riskesdas 2010. Diambil tanggal 21 Juni 2015 dari http:sites/download/bukulaporan/lapnesriskesdas2010/laporan -riskesdas-2010.pdf

Roesli, U. (2009). Panduan Praktis Menyusui. Pustaka Bunda: Jakarta.

Roesli, U. (2008). Inisiasi Menyusui Dini Plus ASI Eksklusif. Pustaka Bunda: Jakarta.
Rukiyah., Yulianti., \& Liana. (2011). Asuhan Kebidanan III (Nifas). CV Trans Info Media: Jakarta.

Sastroasmoro, S \& Ismael, S. (2011). Dasar-dasar Metodologi Penelitian Klinis. CV Sagung Seto: Jakarta.

Sihotang, N.A dan Siregar, F.L.S.(2012). Panduan penulisan karya tulis ilmiah. Medan: tidak dipublikasikan.

Soetjiningsih. (1997). ASI Petunjuk untuk Tenaga Kesehatan. EGC: Jakarta.

Solihah. Dkk. (2007). Faktor-faktor yang berhubungan dengan pemberian ASI dalam satu jam pertama setelah lahir di kabupaten Garut provinsi Jawa Barat. Artikel. Politeknik kesehatan Jakarta.

Sugiono. (2009). Metode Penelitian Pendidikan. CV Alfabeta: Bandung.

Weni Kristiyansari. (2009). ASI Menyusui dan Sadari. Nuha Medika: Yogyakarta. 